\title{
First phylogenetic characterization of Pseudocowpox virus from cattle in Al-Qadisiyah province-Iraq
}

\author{
S.M. Karim ${ }^{1}$, K.A. Mansour ${ }^{1}$, A.H.D. Janabi ${ }^{2}$ and N.K.M. Al-Nakeeb ${ }^{1}$ \\ ${ }^{1}$ Department of Veterinary Internal and Preventive Medicine, ${ }^{2}$ Department of Microbiology, \\ College of Veterinary Medicine, University of Al-Qadisiyah, Al-Diwaniyah, Iraq
}

(Received May 13, 2018; Accepted June 4, 2018)

\begin{abstract}
This study was initiated for the first time for identification, using sequencing and phylogenetic analyses, of pseudocowpox PCPV that inhabit dairy cows in Al-Qadisiyah province, Iraq. Scab sampling was performed to obtain specimens from udder and teats of 18 affected cows. Initially, a polymerase chain reaction (PCR) method was followed to target a 408-bp piece of the GM_CSF/IL-2 inhibition factor gene (GIF) that belongs to PCPV. Then, the PCR products were sent out to partial sequencing of the GIF gene. The results of the PCR have indicated the presence of the virus in only 3 out of 18 samples. When the sequences were studied using phylogeny, the results have revealed that one of our PCPV strains has a close matching with some of the world strains such as from New Zealand. While two of the current study strains have clustered together with a strain from Finland. The results of our study confirm the presence of the PCPV in dairy cows that induces milker's nodules.
\end{abstract}

Keywords: Dairy cows, GIF gene, PCR, Pseudocowpox virus, Sequencing.

Available online at http://www.vetmedmosul.com

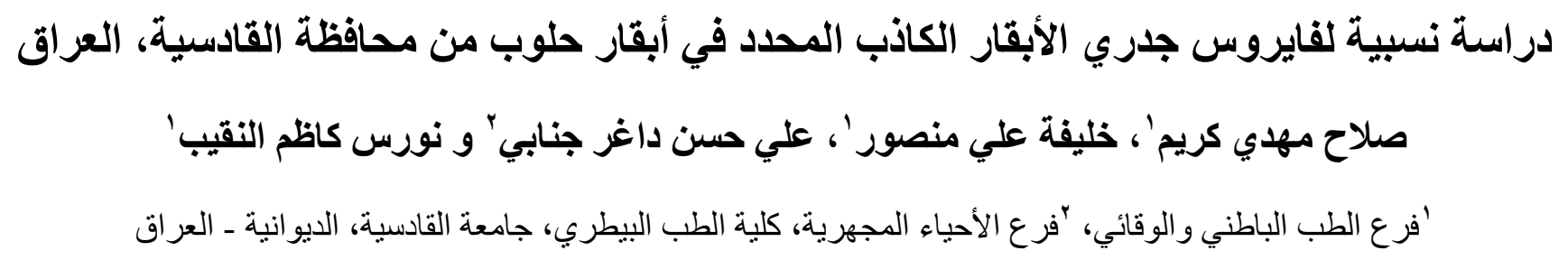

الخلاصة

صممت هذه الدراسة لأول مرة في العراق لتحديد الإصابة بفيروس جدري الأبقار الكاذب، باستخدام تحاليل تعاقب النيوكليوتيدات

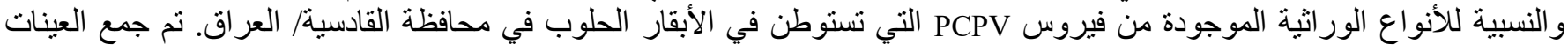

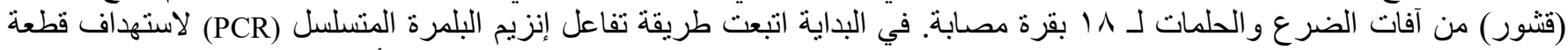

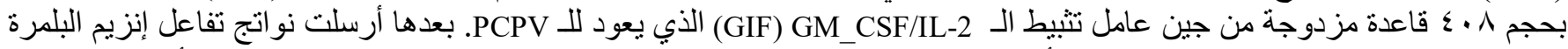

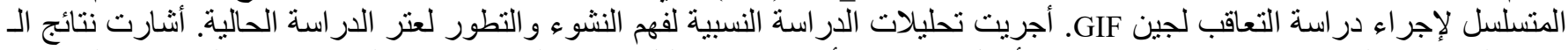

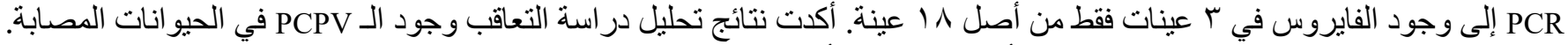

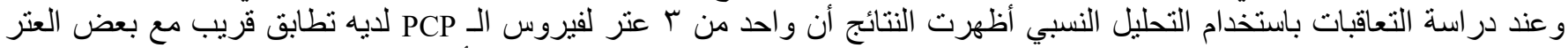

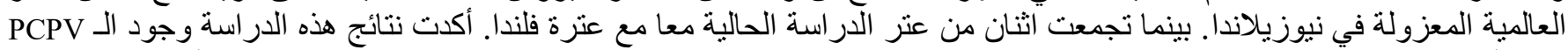

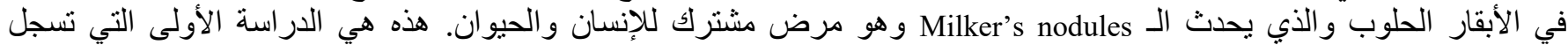
معلومات نسبية لفايروس جدري الأبقار الكاذب و الذي يصيب الأبقار الحلوب في العراق.

\section{Introduction}

Pseudocowpox virus (PCPV) is an etiological agent that causes a world-wide-spread disease of dairy cattle; however, the disease applies low effects on dairy industries (1). The disease is caused by a Parapoxvirus (PPV) that belongs to the Poxviridae and Sub-family Chordopoxvirinae (2). The linear nature of double-stranded 
DNA and the dermotropic affinity to target epithelial cells of the skin are some of the main characteristics of this virus. The virus causes a non-systematic skin-disease in ruminants with the formation of vesicles and eruptions on the affected parts of the skin (3). Previously, the PCPV was called as Parapoxvirus bovis and now is one of two PPVs of ruminants together with Bovine papular stomatitis virus (BPSV) that was previously called Parapoxvirus bovis 1 . The virus induces a zoonotic disease which is known as milker's nodules or pseudocowpox that affects mostly people who in close contact with infected cows (3). The studies that have paid attention to the PCPV were limited to exploring the clinical-finding, electron-microscopic, and/or serological characteristics of the virus (4-6). According to the clinical findings known for PCPV infection, there are multiple-lesion stages that are generated as reactions to this viral infection. These lesions are macules, papules, vesicles, pustules, and scabs (7). Usually following couple of days, the lesions are self-healed after the scabs are self-detached. These lesions could be induced in muzzles of un-weaned calves that suckle milk from affected udders. It has been shown that PCPV has a protein that inactivates the ovine cytokines interleukin-2 (IL-2) and granulocyte-macrophage colony-stimulating factor (GM-CSF). This protein is encoded by GIF gene, which is a unique gene of the PPVs $(8,9)$. Interestingly, the main process that GM-CSF activates is the accumulation and colonization of neutrophils and macrophages in the sites of lesions (10). Using PCR technique was found to be effective in identification of GIF gene (11). Moreover, partialsequencing analysis of the $G I F$-coding gene helps in identifying the existent genotypes of PCPV that inhabit dairy cows (12). The current phylogenetic study of the $\mathrm{PCPV}$ is considered to be the first-time investigation in south of Iraq.

\section{Material and methods}

\section{Sample collection}

Scabs, dried exudate, of teat-skin lesions were collected from 18 local-breed-dairy cows of 3 to 8 years old. These cows were suffering from various udder- and teat-skin lesions. The samples were obtained from those cows in the city center or Al-Qadisiyah, Iraq. The sampling process was last for one month between March, 2017 and April, 2017. Scabs were collected using sterile-artery forceps, and each scab was placed in a $50 \mathrm{ml}$-sterile container. Then, the samples were immediately transported to a laboratory using ice (under cooling using ice pack).

\section{DNA extraction}

To generate a homogenized solution, phosphate buffered saline (PBS) and mechanical crushing were applied to the scab samples following an episode of freeze- thawing process at $20^{\circ} \mathrm{C}$. Genomic DNA extraction tissue $\mathrm{kit}^{\mathbb{R}}$ (Geneaid, USA) was used to extract the viral genomic DNA from the samples. To initiate the process, $200 \mathrm{mg}$ of each scab sample was placed in a $1.5 \mathrm{ml}$ microcentrifuge tube, and tissue-lysis buffer was added to homogenize the mixture using micropestle. Then, the manufacturer's protocol was followed to complete the extraction process. After elution of the purified DNA, the DNA-containing solutions were kept frozen at $-20^{\circ} \mathrm{C}$. The DNA product was evaluated for its quality and quantity using NanoDrop spectrophotometer.

\section{Polymerase chain reaction}

To perform the PCR technique, forward primer (F): GCT CTA GGA AAG ATG GCG TG and reverse primer (R): GTA CTC CTG GCT GAA GAG CG were used to target a 408 bp-DNA-piece of the GIF gene. These primers were picked up from the website of The National Center for Biotechnology Information (NCBI). The mastermix of the PCR reaction was prepared using AccuPower ${ }^{B}$ PCR PreMix kit (Bioneer, South Korea). The premix tubes of the kit had already been pre-loaded by the manufacturer with Taq DNA polymerase $1 \mathrm{U}$, dNTPs $250 \mu \mathrm{M}$, Tris- $\mathrm{HCl}(\mathrm{pH}$ 9.0) $10 \mathrm{mM}, \mathrm{KCl} 30 \mathrm{mM}, \mathrm{MgCl}_{2} 1.5 \mathrm{mM}$, stabilizer, and tracking dye. The preparation of these mastermix solutions was performed using the manufacturer's protocol. In brief, a total volume of $20 \mu \mathrm{l}$ was obtained using $5 \mu \mathrm{l}$ of purified genomic DNA, $1.5 \mu \mathrm{l}$ of 10 pmole from each one of the primers, and $12 \mu \mathrm{l}$ of deionizer PCR water, and then, it was followed by a brief vortexing. After that, the reaction process was initiated using a thermocycler with conditions of initial denaturation temperature at $95^{\circ} \mathrm{C}$ for $5 \mathrm{~min}$, followed by 30 cycles of (denaturation at $95^{\circ} \mathrm{C}$ for $30 \mathrm{~s}$, annealing at $56^{\circ} \mathrm{C}$ for $30 \mathrm{~s}$, and extension at $72^{\circ} \mathrm{C}$ for $45 \mathrm{~s}$ ), and then final extension at $72^{\circ} \mathrm{C}$ for $7 \mathrm{~min}$. Using gel electrophoresis, the PCR products were tested on $1.5 \%$ agarose gel stained with ethidium bromide. After that, the product-containing gel was visualized under a UV illuminator.

\section{$G I F$-partial sequencing}

To prepare the PCR products for the GIF-partial sequencing, these products were purified from agarose gel using EZ-10 Spin Column DNA Gel Extraction $\mathrm{Kit}^{\mathbb{B}}$ (Bio basic, Canada). The purified products were kept frozen at $20^{\circ} \mathrm{C}$ and to be sent later to sequencing. These products were sequenced in both directions using ABI PRISM DNA Sequencing kit $^{\circledR}$ and ABI Sequencer Bio System (Thermo Fisher Scientific, USA). The sequencing was performed at Macrogen Company/ Korea.

\section{Bioinformatics}

The generated sequences of the GIF gene were aligned with some-known sequences of this gene from the NCBI 
website using basic local alignment search tool (Blast). Then, the scores of identities were produced. The alignment process has provided a list of matching viruses to our sequences of the GIF gene. The phylogenetic study was done using the Neighbor-Joining method (13), and the bootstrap replicates were 4000 (14). The distances were computed using the Maximum Composite Likelihood method (15). The phylogenetic analysis was performed using MEGA6 software (16).

\section{Results}

Polymerase chain reaction (PCR) method was followed to target a 408-bp piece of the GM_CSF/IL-2 inhibition factor gene $(G I F)$ that belongs to PCPV. The results of the PCR have indicated the presence of the virus in only 3 out of 18 samples figure 1 .

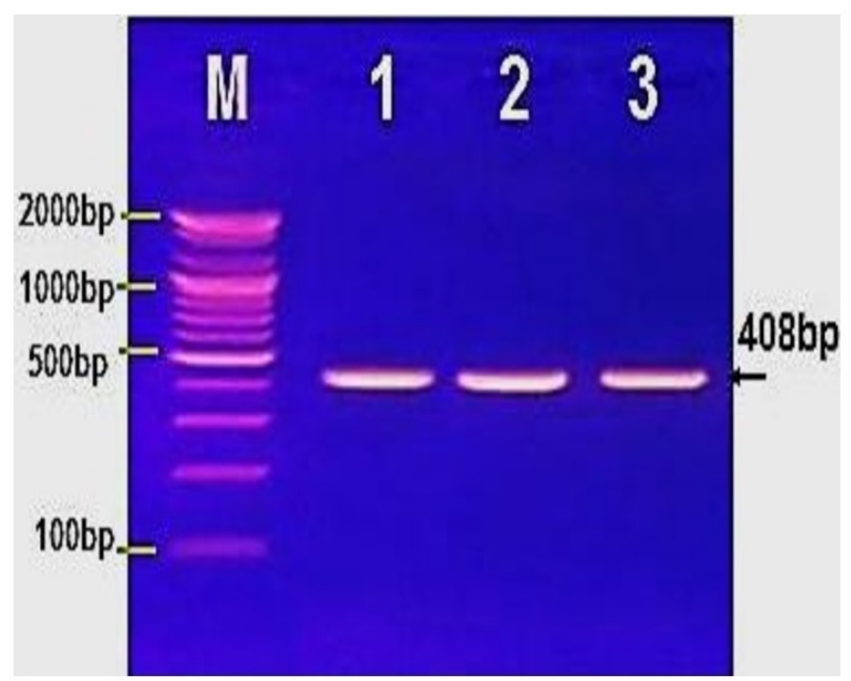

Figure 1: Amplification of the 408-bp piece that belongs to the GIF gene of Pseudocowpox virus on agarose-gel electrophoresis. Lane, M, is the ladder at 100-2000bp. Lanes, 1-3, are the sample-PCR products.

The results of the sequencing analysis have confirmed the presence of PCPV in the infected animals. The partialGIF sequences were deposited in the GeneBank of the NCBI under the accession numbers of MF497785.1, MF497784.1, and MF497783.1. When the sequences were studied using phylogeny, the results have revealed that the MF497783.1 strain was clustered together with GQ329670.1 and Eu999744.1, strains of PCPV from New Zealand, figure 2. While, MF497784.1 and MF497785.1 strain have clustered together with JF773682.1, a cattlePCPV strain from Finland (Figures 2 and 3).

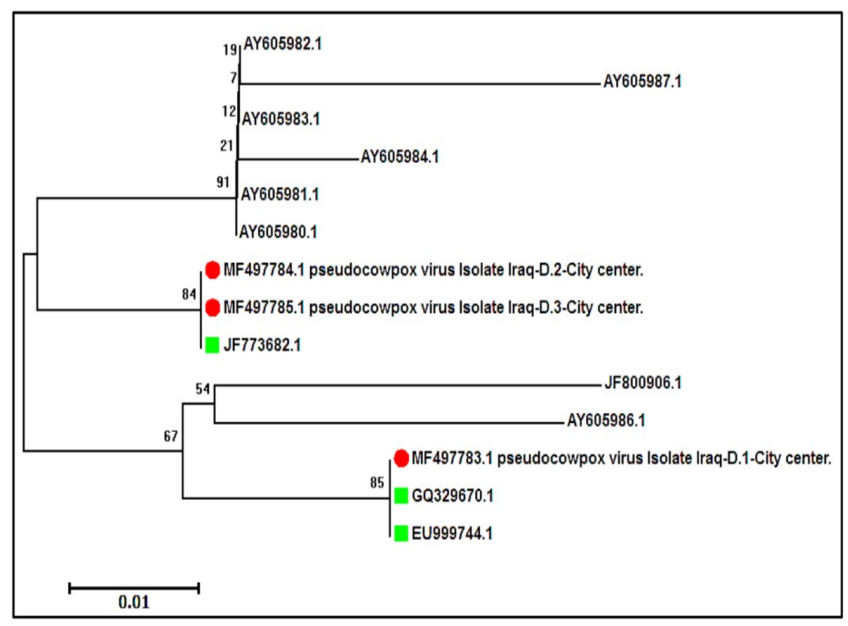

Figure 2: Phylogenetic tree generated by a Neighbor Joining method and based on the amplification of the 408bp piece that belongs to the PCPV-GIF gene. The red spots are the current study strains of the PCPV. The green spots are the world-referenced strains.

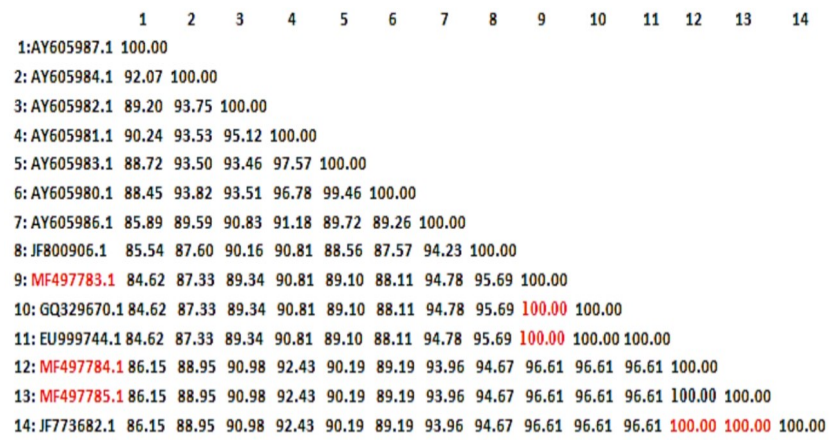

Figure 3: Percent identity matrix- created by Clustal 2.1 .

\section{Discussion}

The results of the current study showed that the PCPV is actually present in infected dairy cows in south of Iraq. Primary relying on the PCR technique has positively confirmed the PCPV infections in the sampled cows. The results have indicated high sensitivity of the PCR technique in identifying the $G I F$-based piece that belongs to the PCPV. These results confirm that using PCR and specific primers could give scientifically approved results (17). The reproducibility and specificity of the results could be improved and guaranteed via proper selections of genetic target and primers alongside with PCR-technique optimization $(18,19)$. Since we have followed these criteria in optimizing our PCR technique, our results indicate high validity for the detection of PCPV in the infected cows. Hence, using GIF-based PCR without relying on highly 
expensive and time-consuming methods such as cell culture system or electron microscopy is an accurate and scientifically trusted choice. Therefore, it is considered as an accurate tool to diagnose and identify the PCPV from skin scabs of infected cows. Interestingly, only 3 out of 18 animals were positive for PCPV, and that could be reasoned to the fact that many teat-skin diseases share the exact same clinical lesions. The PCR-negative results for the 15 animals indicate that these animals might have had completely different teat-skin diseases such as cowpox, udder impetigo, bovine ulcerative mammalities, foot and mouth disease, and teat fibropapilloma (20).

Interestingly, the results of the sequencing have revealed three sequences but two distinct phylogenies of the PCPV that had affected the sampled animals. These distinct sequences were aligned with strains from New Zealand and Finland $(21,22)$. The evolutional history indicates that our strains might originally have descended from the same ancestor as for the New Zealand and Finland strains. In the previous century, Iraq had imported foreign breeds of cows such as Holstein and Frisian. This piece of fact could demonstrate that Iraqi local breeds might have adopted the PCPV from those foreign breeds when both had come into contact. In a different scenario, it is also possible that our strains might have evolutionally developed to be in very close matching to the New Zealand and Finland strains.

This study was concentrated on the rapid diagnosis of the PCPV infection in dairy cattle using PCR. The presence of the PCPV that was detected in this study could also reveal the presence of the zoonotic PCPV or milker's nodules. The phylogenetic analysis of the PCPV gives ideas and understanding about the existent genotypes of this virus in south of Iraq. It also helps providing epidemiologist with feasible information to track and control the virus in Iraq, neighbor countries, or the world. To the best of our knowledge, no study has been done to investigate the Pseudocowpox virus in Iraq using sequencing of the GIF gene of this virus.

\section{Acknowledgments}

We appreciate and thank the farmers who allowed us to perform the sampling process.

\section{References}

1. Munz E, Dumbell K. Pseudocow pox. In: Coetzer JAW, Thomson GR, Tustin RC, editors. Infectious disease of livestock, $1^{\text {st }}$ ed. Oxford: Oxford University Press; 1994. p. 625-626.

2. Gallina L, Scagliarini L, McInnes CJ, Guercio A, Purpari G, Prosperi S, Scagliarini A. Parapoxvirus in goats: experimental infection and genomic analysis. Vet Res Com. 2008;32:203-205.
3. Flemming SB, Mercer AA. Genus Parapoxvirus. In: Mercer AA, Schmidt A, Weber O, editors. Poxviruses, $1^{\text {st }}$ ed. Berlin: Birkhauser Verlag; 2007. p. 127-165.

4. Abrahao JS, Guedes MI, Trindade GS. One more piece in the VACV ecological puzzle: could peridomestic rodents be the link between wildlife and bovine vaccinia outbreaks in Brazil. PLoS One. 2009;4:e7428.

5. Ohtani A, Yokoyama A, Narushige H, Inoshima Y. First isolation and genetic characterization of pseudocowpox virus from cattle in Japan. Virol J. 2017;14(1):172.

6. Schatzmayr HG, Lemos ER, Mazur C. Detection of poxvirus in cattle associated with human cases in the State of Rio de Janeiro: preliminary report. Mem Inst Oswaldo Cruz. 2000;95:625-627.

7. Alves PA, Figueiredo PO, de Oliveira CHS. Occurrence of Pseudocowpox virus associated to bovine viral diarrhea virus-1, Brazilian Amazon. Comp Immunol Microbiol Infect Dis. 2016;49:7075.

8. McInnes CJ, Deane D, Haig D, Percival A, Thomson J, Wood AR. Glycosylation, disulfide bond formation, and the presence of a WSXWS-like motif in the orf virus GIF protein are critical for maintaining the integrity of Binding to ovine granulocyte macrophage colony-stimulating factor and interleukin-2. J Virol. 2005;79:1120511213.

9. Fleming SB, Wise LM, Mercer AA. Molecular genetic analysis of orf virus: a poxvirus that has adapted to skin. Viruses. 2015;7(3):15051539 .

10. Strockbine LD, Cohen JI, Farrah T, Lyman SD, Wagener F, DuBose RF, Armitage RJ, Spriggs MK. The Epstein-Barr virus BARF1 gene encodes a novel, soluble colony-stimulating factor-1 receptor. J Virol. 1998;72:4015-4021.

11. Espy MJ, Uhl JR, Sloan LM, Buckwalter SP, Jones MF, Vetter EA, Yao JD, Wengenack NL, Rosenblatt JE, Cockerill FR, Smith TF. Real-time PCR in clinical microbiology: applications for routine laboratory testing. Clin Microbiol Rev. 2006;1:165-256.

12. MacNeil A, Lederman E, Reynolds MG, et al. Diagnosis of bovineassociated parapoxvirus infections in humans: molecular and epidemiological evidence. Zoon Pub Heal. 2010;57:e161-e164.

13. Saitou N, Nei M. The neighbor-joining method: A new method for reconstructing phylogenetic trees. Mol Biol Evol. 1987;4:406-425.

14. Felsenstein J. Confidence limits on phylogenies: An approach using the bootstrap. Evol. 1985;39:783-791.

15. Tamura K, Nei M, Kumar S. Prospects for inferring very large phylogenies by using the neighbor-joining method. Proc Nat Aca Sci. 2004;101:11030-11035.

16. Tamura KG, Stecher D, Peterson A, Filipski S, Kumar S. MEGA6: Molecular evolutionary genetics analysis version 6.0. 2013.

17. Klein J, Tryland M. Characterisation of parapoxviruses isolated from Norwegian semi-domesticated reindeer (Rangifer tarandus tarandus). Virol J. 2005;2:79.

18. Luo K, Wang Q, Qiu Q, Li X, Jia X, Chen X, Zhang Z, Zheng G, He Z. Simultaneous amplification of exons 18 to 21 of the EGFR gene using $5^{\prime}$ tailed primers and a two-stage protocol. Nucl Acid. 2018;16:1-19.

19. Neha, Verma AK, Kumar A, Ahmed I. Comparative efficacy of serological diagnostic methods and evaluation of polymerase chain reaction for diagnosis of bovine brucellosis. Iranian Jo Vet Res. 2017;4:279-281.

20. Fenner FJ, Gibbs E, Paul J, Murphy FA, Rott R, Studdert MJ, White DO. Veterinary virology. $2^{\text {nd }}$ ed. London: Academic Press; 1993.

21. Deane D, Ueda N, Wise LM. Conservation and variation of the parapoxvirus GM-CSF-inhibitory factor (GIF) proteins. J Gen Virol. 2009;90(4):970-977.

22. Hautaniemi M, Vaccari F, Scacliarini A. Analysis of deletion within the reindeer pseudocowpoxvirus genome. Virus Res. 2011;160(12):326-332. 